\title{
HOUSING OF DANISH DAIRY HERDS AND ANALYSIS OF VARIATION IN TREATMENT FREQUENCIES IN PRODUCTION SYSTEMS
}

\author{
Marlene Trinderup, Lars Arne Hjort Nielsen, and Anne Mette Kjeldsen \\ National Department of Cattle Husbandry; Udkærsvej 15; DK-8200 Aarhus N; Denmark; \\ Phone: 87405000; Fax: 87405010; Email address: mat@1r.dk
}

The objective of this study was to document the variation of housing of Danish dairy herds and analyse the variation of production and animal health in production systems. The use of summer grazing was also analysed.

In November 2000 information on housing systems in herds participating in the Milk Recording Sceme was collected by the milk recording field technicians. The informations collected concerned type of housing (free stall or tie stall), type of manure and information about whether or not the farmer was grazing his herd. A similar collection was effected in November 1996. Data on production and health were obtained from the Danish Cattle Database.

A total of 8,003 herds participated. $37 \%$ of the herds (53\% of the cows) were housed in free stalls, whereas $62 \%$ of the herds ( $46 \%$ of the cows) were housed in tie stalls. Thus, the average herd size for herds housed in free stalls is larger (98 cows) than the herd size for herds housed in tie stalls (52 cows). From 1996 to 2000 there has been an increase from $21 \%$ to $37 \%$ of herds housed in free stalls. Summer grazing were offered in $86 \%$ of the herds. On average, the herds housed all year round were larger than the herds offered summer grazing.

The production was higher in cubicle stalls than in other stalls (eg. Danish Holstein in cubicles had obtained a yield consisting of $17 \mathrm{~kg}$ more fat + protein than in the other types of housing). The somatic cell count seemed to be highest in deep litter stalls (eg. Danish Holstein: 344,000 in deep litter stalls and 290,000 in cubicle stalls).

Binomial logistic regression was used to estimate the effect of production system, grazing, breed, and total milk yield on the number of treatments relative to the total number of cows per herd. Only herds using a veterinarian with a known systematic registration of treatments was included in the analysis. Tabel 1 shows a selection of treatments and the estimated frequencies in the four production systems. There was an effect of breed and an increase of milk yield increased the frequency of treatments. There was only a slight effect of grazing.

Table 1. Mean herd level frequencies of treatments (\%) in different production systems.

\begin{tabular}{lccccc}
\hline Treatments & Number & \multicolumn{2}{c}{ Tie-up cowhouse } & \multicolumn{2}{c}{ Free-stall housing } \\
& of herds & Farmyard manure & Slurry & Cubicles & Deep litter \\
\hline Mastitis & 3,934 & $37.2^{\mathrm{a}}$ & $37.0^{\mathrm{a}}$ & $33.9^{\mathrm{b}}$ & $40.6^{\mathrm{a}}$ \\
Teat damage & 4,038 & $0.51^{\mathrm{a}}$ & $0.71^{\mathrm{b}}$ & $0.21^{\mathrm{c}}$ & $0.07^{\mathrm{d}}$ \\
Ketosis & 4,038 & $2.0^{\mathrm{a}}$ & $1.4^{\mathrm{b}}$ & $0.9^{\mathrm{c}}$ & $1.1^{\mathrm{c}}$ \\
Parturient Paresis & 4,038 & $5.4^{\mathrm{a}}$ & $4.5^{\mathrm{b}}$ & $3.6^{\mathrm{c}}$ & $4.4^{\mathrm{b}}$ \\
Lameness & 4,037 & $5.6^{\mathrm{a}}$ & $5.8^{\mathrm{a}}$ & $8.2^{\mathrm{b}}$ & $7.8^{\mathrm{b}}$ \\
Obstetric & 4,038 & $1.4^{\mathrm{a}}$ & $1.1^{\mathrm{b}}$ & $1.0^{\mathrm{b}}$ & $0.6^{\mathrm{c}}$ \\
Retained Placenta & 4,038 & $6.6^{\mathrm{a}}$ & $6.8^{\mathrm{a}}$ & $6.4^{\mathrm{a}}$ & $8.5^{\mathrm{b}}$ \\
Reproduction & 4,038 & $2.2^{\mathrm{a}}$ & $2.2^{\mathrm{a}}$ & $3.4^{\mathrm{b}}$ & $2.9^{\mathrm{b}}$ \\
\hline
\end{tabular}

a,b,c,d values in rows with different indices differ significantly $(\mathrm{p}<0.05)$ 